\title{
Pendidikan Perempuan SEXI DANCER di Yogyakarta
}

\author{
Oleh : \\ Aris Martiana, V. Indah Sri Pinasti, Puji Lestari ${ }^{1}$
}

\begin{abstract}
ABSTRAK
Istilah Sexi Dance sudah tidak asing lagi didengar di dunia hiburan dan bahkan penarinya berstatus mahasiswa. Pendidikan yang dialami menarik untuk diteliti. Penelitian ini bertujuan untuk mengetahui gambaran tentang pendidikan yang dialami perempuan berstatus mahasiswa yang bekerja sebagai sexi dancer di daerah Yogyakarta. Penelitian ini menggunakan kualitatif deskriptif untuk melihat fenomena sosial secara holistik dan mendalam. Sesuai dengan tujuan digunakan teknik cuplikan snowball sampling yakni dengan memiliki informan kunci yang kemudian dari informan tersebut mendapatkan informan selanjutnya untuk teknik pengumpulan data digunakan wawancara dan dokumentasi. Analisis data dilakukan dengan menggunakan model interaktif.

Temuan penelitian menunjukkan gambaran bahwa di dalam pendidikan informal yakni keluarga, informan mengalami adanya pengekangan dengan aturan yang ditetapkan oleh keluarga, adanya nilai agama dan pengetahuan umum yang diajarkan dalam keluarga, etika dan berbuat baik terhadap oranglain. Sedangkan pendidikan secara formal mereka berada pada jenjang perguruan tinggi ternama di daerah Yogyakarta dengan nilai yang baik. Kemudian di masyarakat, mereka belum terjun langsung secara total dalam kegiatan masyarakat, hanya mengikuti kegiatan di kampus dan kelompok menarinya. Adanya temuan di lapangan bahwa untuk pekerjaan sebagai sexi dancer belum banyak orang yang mengetahui baik dari pihak keluarga maupun masyarakat, tetapi hanya beberapa teman mengetahui pekerjaan tersebut dilakukan selain berstatus sebagai mahasiswa.
\end{abstract}

Kata Kunci: Pendidikan, Perempuan, Sexi Dancer, Keluarga, Sekolah, Masyarakat

${ }^{1}$ Dosen Jurusan Pendidikan Sosiologi, Universitas Negeri Yogyakarta (aris_martiana@uny.ac.id), 085647088310 


\section{PENDAHULUAN}

Pendidikan merupakan sebuah proses yang secara alamiah dialami oleh manusia. Proses yang terdapat didalamnya sebuah pembelajaran tentang pengetahuan dan penanaman kebiasaan, nilai, norma dan budaya masyarakat. Individu belajar dari lingkungannya sehingga ia menjadi sosok yang diharapkan dan sesuai dengan kehidupan masyarakatnya. Proses pembelajaran tersebut dilakukan dalam tiga lingkup lembaga yakni keluarga sebagai tempat yang pertama individu mempelajari lingkungannya, sekolah adalah agen sosialisasi sekunder yang secara formal menjadi tempat pembelajaran individu. Lembaga yang berjenjang dengan kurikulum serta legalitas ijazah kelulusan yang melekat dalam pendidikan formal di sekolah. Berikutnya adalah lembaga masyarakat, individu mendapatkan pengetahuan dan nilai norma sosial budaya yang ada di lingkungan keseharian mereka. Masyarakat yang memiliki heterogenitas tinggi berfungsi sebagai pembelajaran individu karena di dalamnya memiliki semua hal yang dibutuhkan oleh individu. Kebiasaan, nilai dan norma yang ada di masyarakat dipelajari dan diinternalisasikan dalam dirinya sehingga akan mampu membentuk kepribadian individu. Ada interaksi dengan individu lainnya, hal itu yang terjadi dalam individu mempelajari lingkungan diperkuat dengan yang disampaikan oleh James M.Henslin (2006) yaitu ...melalui kontak manusialah orang dapat belajar menjadi anggota komunitas manusia. Proses melalui mana kita belajar cara-cara masyarakat (atau kelompok tertentu) ini, yang dinamakan sosialisasi (socialization) adalah apa yang ada dalam benak para sosiolog dikala mereka berkata bahwa "masyarakat menjadikan kita manusiawi."

$$
\text { Sosialisasi sebagai proses }
$$

pemahaman dan belajar individu dengan lingkungannya juga dialami oleh perempuan yang bekerja sebagai sexi dancer. Perempuan tersebut berstatus sebagai mahasiswa di daerah Yogyakarta. Secara perkembangan individu menurut Elizabeth B.Hurlock (1968) usia 17 tahun sampai 21 tahun masuk pada masa remaja akhir (Panut Panuju\&Ida Umami, 2005). Fase remaja akhir yang menjadi fase peralihan dari remaja menuju ke masa dewasa. Ketika diusia tersebut sudah mengalami kestabilan secara psikologis dan memiliki pengetahuan yang cukup karena mengenyam pendidikan tinggi kemudian mereka memutuskan untuk memilih menjadi sexi dancer. Penari dengan penampilan dan gerakan sexi bahkan kostum yang dikenakan sangat minimalis lalu melakukan pertunjukkan dipanggung saat malam hari bersama penonton yang sebagian besar adalah kaum laki-laki sehingga seolah-olah hal yang sexi secara fisik sudah bukan hal yang tabu lagi untuk dibicarakan maupun dilihat di ruang publik. Baudrillard menegaskan bahwa, ketika manusia diperbolehkan melihat, 
mempertontonkan, melakukan atau merepresentasikan yang sebelumnya dianggap tabu, amoral, bahkan abnormal maka sebenarnya tidak ada lagi rahasia di dalam dunia realitas. Bahkan realitas seksual itu sendiri sebenarnya sudah tidak ada sebab ia hanya bisa ada bila masih ada sesuatu yang dirahasiakan yang direpresentasikan untuk difantasikan. Yang tersisa sekarang melalui perkembanganbiakan bentuk-bentuk baru (pelanggaran) citra seksual adalah hiperealisme kesenangan (Piliang,1998; Ellys Lestari P,2010). Penari dengan penampilan fisik baik wajah yang cantik bermakeup panggung, pakaian dan pernak-pernik panggung yang sangat minimalis ukurannya dikenakan ditubuh mereka dan gerakangerakan sensual yang diiringi musik sangat apik dilihat bagi penonton yang hadir dipertunjukkan tersebut.

Penari memiliki alasan melakukan tindakan tersebut. Keputusan untuk melakukan tindakan berasal dari motifasi yang dipengaruhi oleh berbagai faktor bahkan faktor tersebut dari dalam dan luar individu. Bagi Hamzah B. Uno (2014) motifasi adalah dorongan dasar yang menggerakkan seseorang bertingkah laku...motivasi adalah kekuatan, baik dari dalam maupun dari luar yang mendorong seseorang untuk mencapai tujuan tertentu yang telah ditetapkan sebelumnya. Motifasi yang dimiliki sangat bervariasi dimiliki oleh para penari khususnya yang berstatus sebagai mahasiswa. Banyak faktor yang mempengaruhi mereka bahkan termasuk kehidupan pribadinya. Meskipun secara penampilan mereka dipanggung sangat vulgar namun mereka disisi belakang panggung yakni kehidupan nyatanya memiliki hal yang tidak berbeda dengan mahasiswa perempuan lainnya. Salah satunya adalah pendidikan yang dialami secara lingkup keluarga, sekolah dan masyarakat. Perempuan sexi dancer dalam mendapatkan pendidikan yang menjadi faktor pembentuk karakter dan kepribadiannya sangat menarik untuk diteliti sehingga keingintahuan akan sesuatu hal dibalik fenomena menjadi semakin kuat sehingga riset ini mampu menguraikan peristiwa pendidikan yang dialami oleh perempuan sexi dancer dalam keluarga, sekolah dan masyarakat.

\section{METODOLOGI}

Penelitian yang digunakan adalah dengan menggunakan metode kualitatif deskriptif, untuk dapat mendeskripsikan pendidikan yang dialami mahasiswa perempuan sebagai sexi dancer secara rinci. Kajian dalam penelitian ini adalah perempuan sebagai sexi dancer yang berstatus sebagai mahasiswa. Banyaknya masyarakat urban yang berada di daerah Yogyakarta kemudian informan tinggal dan belajar disana serta daerah tempat mereka menari di klub malam. Sesuai dengan judul yang diambil perempuan 
berarti informan yang digunakan adalah perempuan berstatus sebagai mahasiswa yang sebagian besar berasal dari luar kota kemudian tinggal di Yogyakarta. Penelitian ini memiliki 4 informan yang berasal dari perguruan tinggi yang identitasnya disamarkan dengan menggunakan inisial antara lain: DT, IM, IN, dan AN. Teknik cuplikan sampling dilakukan dengan menggunakan snowball sampling. Peneliti menemukan kunci informan dahulu kemudian dari dia ditemukan informan lain yang sama sebagai sexi dancer. Setelah itu maka didapatkan informan kembali sehingga data yang dibutuhkan tercukupi. Teknik ini tepat sekali digunakan karena peneliti belum mengetahui tentang informan sexi dancer. Sedangkan Teknik Pengumpulan Data yang digunakan adalah dengan (1) wawancara yaitu teknik ini menggunakan pedoman berisi daftar pertanyaan yang merupakan garis besar tentang bahan untuk didiskusikan dalam penelitian lalu dilakukan pengembangan pertanyaan untuk memperdalam informasi. Pelaksanaan wawancara dilakukan secara terbuka sehingga informan mengetahui bahwa sedang diadakan penelitian dan informan menjadi salah satu sumber informasi., (2). Dokumentasi, teknik ini menggunakan beberapa dokumen berupa hasil-hasil penelitian lainnya yang sudah dijurnalkan, foto informan saat pertunjukkan dan beberapa informasi berita terkait dengan sexi dancer.

Dalam penelitian ini menggunakan trianggulasi metode yaitu pengumpulan data dengan teknik pengumpulan data yang berbeda. Teknik yang digunakan yaitu interview dan dokumentasi sehinggga data lebih akurat. Teknik analisis data yang digunakan dalam penelitian ini adalah mendeskripsikan secara holistik tentang hasil penelitian tersebut. Penelitian ini menggunakan teknik analisa data kualitatif dengan model interaktif Miles \& Huberman. Aktivitas analisis data model ini adalah reduksi data, sajian data, dan penarikan kesimpulan. ...tiga hal utama yaitu reduksi data, penyajian data dan penarikan kesimpulan/verifikasi sebagai sesuatu yang jalin menjalin pada saat sebelum, selama, dan sesudah pengumpulan data dalam bentuk sejajar untuk membangun wawasan umum yang disebut analisis (Miles \& Huberman, 1992).

\section{HASIL}

Perempuan sexi dancer pada umumnya adalah perempuan yang melakukan perilaku menari secara sexi baik dari segi penampilan maupun dari gerak tariannya. Gerakan yang dilakukan selalu serasi dengan musik dan kostum yang dikenakan juga sesuai dengan tema pertunjukan. Perempuan cantik dengan dandanan molek menari di berbagai event dan juga beberapa klub malam di Yogyakarta yang tak pernah sepi akan kegiatan manusia dari pagi hingga malam hari 
menjadikan tarian tersebut cukup populer. Perempuan tersebut tidak dapat langsung dikenali sebagai sexi dancer kecuali memang sudah mengenalnya dengan baik. Mereka tergabung dalam kelompok managemen tarian yang berjumlah banyak diberbagai sudut daerah Yogyakarta dalam dunia hiburan. Penari ada yang mengikuti lebih dari satu managemen dan ada yang tidak bergabung dengan managemen. Mereka akan mendapatkan pekerjaan untuk menari di berbagai pertunjukan dengan memiliki jaringan interaksi yang luas dengan orang lain sehingga penari sangat supel dan mudah berteman dengan siapa saja. Mereka juga sebagai seorang individu yang mengalami pendidikan baik di lingkungan keluarga, sekolah maupun masyarakat yang berbedabeda satu dengan lainnya. Berikut temuan sebagai hasil dari penelitian di lapangan :

1) Pendidikan dalam Keluarga

Keluarga sebagai tempat pertama dan utama dalam individu mendapatkan pendidikan sehingga peran keluarga sebagai lembaga informan sangat penting. Banyak hal yang diajarkan dalam keluarga seperti nilai, norma, dan pengetahuan. Bidang sosial dan budaya adalah hal yang selalu ada diberikan pada anak. Hal positif selalu diberikan untuk anak oleh orangtuanya, seperti yang diungkapkan oleh DT sebagai berikut:

"Untuk yang diajarkan dikeluarga saya lebih kepada kepengetahuan umum secara keseluruhan, untuk tentang keagamaan tidak terlalu ditekan dalam keluarga “ (W/DT/16/8/2016)

Sejalan dengan AN dengan pengetahuan umum dan keagamaan yang diberikan pula dikeluarga meskipun dengan porsi yang berbeda yaitu :

"Pembelajaran dikeluarga lebih kepada pengetahuan umum akan tetapi tidak lepas dari pengetahuan keagamaan islam"

(W/AN/15/8/2016)

Lain halnya dengan IN yang berasal dari luar daerah Yogyakarta mengatakan bahwa :

"Harus bersikap baik terhadap orang, kalo dari keluarga saya lebih didikannya cuek, mamah saya juga cuek, kalo mengekang sih iya mengekang tapi karena saya bandel sih ya jadi yaa tetep melanggar. Kalo saya disini paling jangan terlalu percaya sama orang hargai diri sendiri aja." (W/IN/7/9/2016)

Begitu juga untuk IM yang asli berasal dari daerah Yogyakarta mengatakan :

"Ajaran yang dominan adalah etika, sosialisasi, saya tinggal di kota jadi sosialisasi saya dengan lingkungan sangat sedikit, lebih sering diajarkan keluarga kalo ke keluarga sosialisasinya bagus acara keluarga juga sering ikut.” (W/IM/15/8/2016)

Mereka masih menyembunyikan pekerjaannya sebagai sexi dancer dari keluarga, seperti yang disampaikan oleh AN yaitu :

"Untuk keluarga tidak ada yang tahu, kalau tahu bisa enggak diperbolehkan. Pada saat itu mamah pernah nanya kamu nari seperti yang 
di TV itu yah, trus saya menjawab tidak ko mah. Kalau dari keluarga sendiri belum ada yang mengetahui kalau saya bekerja di sexi dancer. Kalau temen-temen di Bandung mengetahui kalau aku sexi dancer." (W/AN/15/8/2016)

Seperti yang disampaikan oleh DT bahwa : "Orang tua belum mengetahui lebih lanjut, hanya mengetahui aku nari malam saja tapi belum tahu sebagai sexi dancer" (W/DT/16/8/2017).

IM juga mengatakan hal yang serupa tentang orangtuanya yaitu :

"Orang tua ya paling tahunya saya sebagai penari dance modern Cuma kalo sexy dancer sepertinya engga walaupun kadang saya perginya pake pakaian seksi tapi ngga yang seksiseksi banget namun jika pamit saya pamitnya paling perform di kafe, orang tua tahu kalau saya hobi nari jadi dari pada nantinya jika saya ngga izin tapi pulang-pulang liat make up dan baju yang seksi mending diawal saya pamit mau perform tapi ga pamit mau perform sebagai sexy dancer." (W/IM/15/8/2016)

Lain ceritanya dari AN tentang pekerjaannya dan keluarga, berikut yang disampaikan :

"Dulu engga tapi sekarang mamahku aja yang tahu, jadi cerita ini ya, jadi jaman aku long trip jadi sexy kan ada long trip atau tour kan, saya long trip saya beli oleh oleh ke mamahku, trus mamah cerita punya temen baik saya juga beliin kain ke temennya mamah, engga lama trus mamahku telpon “dek kamu lagi ngapain si”, kok agak aneh saya bilangnya ga ngelakuin apa apa, tapi tuh mamah yang nanyain sambil nangis kenapa kenapa, jadi kain yang dikasih sama saya ke temen mama saya tu ada kejadian aneh, jadi temennya itu naik haji dan kainnya dibawa dan kain itu keluar darah terus dicuci gak ilang terus mama nelfon nangis nangis, ya saya akhirnya jujur kalo IN disini sering nari-nari seksi, disini saya sexy dancer tapi ga jual diri, mama marah ya mamah bilang jangan kaya gitu, disitu saya bilang, "mamah saya minta maaf" terus mamah bilang cuma pengen saya kuliah, dari situ saya terus long trip banyak sampe banyak uang buat kuliah kemudian berhenti buat fokus kuliah, eh sekarang gitu lagi karena ada job tapi mamah juga tahu,sekarang lebih di bolehin ya yang penting kalo emang kamu kaya gitu ya cukup disitu jangan bawa ke dunia lain jangan upload foto yang lagi begituan jangan, ya orang kan nganggep ga bener nantinya, disitu saya janji juga kalo udah lulus saya berhenti. Mamahku tau juga saya kaya gini ya demi kebutuhan sehari-hari juga. (W/IN/7/9/2016).

\section{Pendidikan dalam Sekolah}

Sexi Dancer yang menjadi informan adalah mereka berstatus sebagai mahasiswa di perguruan tinggi ternama di daerah Yogyakarta. Mereka mendapatkan sosialisasi dalam jenjang formal. Mereka juga belajar tarian dari sekolahnya sehingga keahlian menarinya semakin bagus. Seperti penuturan IN:

"Hobby banyak tapi ga fokus satu gitu, semua ya saya seneng ga terlalu seneng, nari juga sebenarnya bukan hobi, saya nari pun bisanya pas kuliah kuliah ini, kalo dibilang mungkin lebih ke kesenian karena dulu SMA saya teater." (W/IN/7/9/2016). 
DT juga mengatakan bahwa :

"Kalau hobi tari soalnya dari SD sudah diajari tari tapi lebih kepada tarian tradisional sampai ikut kesanggar juga, SMP tidak ikut kegiatan dan SMA kelas 2 mulai ikut tari tapi lebih kepada yang modern. Kalau yang saya sukai lebih kepada Nari, soalnya kuliah juga masuk jurusan Tari, jadi mau enggak mau ya saya suka Tari. (W/DT/16/8/2017)

Lain halnya AN yang mengaku sudah mengalami ketidaksukaannya dalam perkuliahan karena dia sudah di tingkat akhir, berikut ini pengakuannya :

"Yang saya tidak sukai sekarang ini kuliah, karena sudah semester tua jadi makin sulit. Untuk kegiatan kampus pernah sih ikut, seperti jadi pelatih nari” (W/AN/15/8/2016)

\section{Pendidikan dalam Masyarakat}

Pendidikan yang didapatkan informan juga dialami dalam lingkup masyarakat namun mereka ada beberapa yang tidak mengikuti banyak kegiatan secara langsung dalam masyarakat karena mereka berstatus sebagai mahasiswa yang lebih fokus pada kegiatan di lingkungan kampusnya.

Seperti yang dikatakan oleh IN yaitu :

"Kalo kuliah sekarang si engga, kalo dulu SMA ikut modeling, di sini pun walau saya suka dance kalo saya organisasi dance engga ikut, disini saya nari lebih ke job dari ajakan. baksos pernah kepanitiaan mungkin kan IS sering mengadain acara pertunjukan pentas nah saya sering jadi panitia disitu, misal saya yang jadi crew juga" (W/IN/7/9/2016)

Namun ada juga yang tidak mengikuti kegiatan untuk masyarakat ataupun dilakukan dalam masyarakat. Seperti penuturan AN :

\begin{abstract}
"Kegiatan diluar rumah saya tidak ada selain latihan nari. Kalau di masyarakat tidak ada akan tetapi kalau dikampus sering ikut latihan tari. Lumayan banyak sih, kemarin ikut dance Icon, IMB 2 sampai 13 besar. Hampir kebanyakan yang saya ikuti yang berkaitan dengan Tari, untuk yang lain saya tidak terlalu mengikuti karena saya tipe orang yang tertutup" (W/AN/15/8/2016)
\end{abstract}

Lain dengan IM mengatakan bahwa :

"Iya saya mengikuti organisasi dance group,group itu lebih kepada tarian modern dan korean bukan sexy dancer kalo sexy dancer itu lebih ke job kaloada tawaran baru berperan menjadi sexi dancer. Dulu saya pernah mengikuti baksos di kampus kemudian sekarang lagi KKN kan KKN termasuk kegiatan masyarakat dan posyandu juga pernah. (W/IM/15/8/2016)

\section{DISKUSI}

Proses individu belajar tentang ilmu pengetahuan dan kebudayaan di lingkungan sekitarnya sebagai proses pendidikan yang alamiah. Pengalaman belajar yang didapatkan individu dari kehidupan sekitarnya karena lingkungan yang menulisi individu tersebut. Ada transfer budaya, penanaman nilai dan norma serta kebiasaan yang terjadi pada sekelompok masyarakat. Pendidikan yang 
terjadi memiliki tujuan salah satunya adalah pembentukan karakter individu yang sesuai nilai dan norma. Kebutuhan pendidikan sangat diperlukan individu karena dengan pendidikan maka kemandirian dan karakter terbentuk sehingga akan membentuk kebudayaan yang beradab serta bermanfaat bagi kehidupan bersama. Filsafat timur (India) oleh J. Krishnamurti, 1979 dalam bukunya Agus Salim (2008) mengartikan bahwa pendidikan adalah perubahan batin untuk membentuk kebudayaan baru; menurut Krishnamurti pendidikan memiliki arti yang sangat penting dalam menyampaikan apa yang pokok untuk perubahan batin manusia dan membentuk budaya baru. Perubahan yang fundamental itu terjadi apabila si anak, sementara dilatih dalam berbagai ketrampilan dan ilmu pengetahuan, juga diberi kemampuan untuk menyadari proses-proses pikiran, perasaan, dan tindakannya sendiri. Kewaspadaan ini membuat si anak kritis terhadap diri sendiri dan cermat pengamatannya dan dengan demikian membentuk keutuhan penglihatan, perbedaan, dan tindakan yang sangat penting untuk pendewasaan di dalam dirinya bagi suatu hubungan yang benar terhadap sesama manusia, terhadap alam, dan terhadap alat-alat yang diciptakan manusia. Pendidikan dengan orientasi menjadi manusia yang sesungguhnya dengan memanusiakan manusia tidak terlepas dari hakikat hidupnya sebagai makhluk individu dan pribadi, makhluk Tuhan juga makhluk sosial budaya. Hakikat sebagai manusia akan dapat dengan mudah dipahami melalui pendidikan. Pendidikan yang dialami individu antara lain pendidikan keluarga, sekolah dan masyarakat. Pendidikan terkecil dalam masyarakat terjadi di dalam keluarga, namun keluarga menjadi dasar/pondasi dalam membentuk pribadi dan karakter individu. Sexi dancer juga mengalami proses pendidikan seperti dialami oleh orang lain, berikut penjelasan pendidikan yang saat ini mengenyam pendidikan tinggi di perguruan tinggi ternama di Yogyakarta antara lain :

a. Pendidikan dalam keluarga

Pendidikan keluarga atau yang sering disebut dengan pendidikan informal adalah proses pendidikan dalam keluarga inti dan luas. Pendidikan tersebut berkaitan erat dengan sosialisasi individu dalam mempelajari nilai dan norma serta kebiasaan lingkungan dalam keluarga. Pendidikan keluarga merupakan pendidikan pertama dan utama yang dialami oleh individu. Sosialisasi dan enkulturasi terjadi dalam keluarga sehingga mereka akan mempelajari dan menanamkan dalam sanubari hal yang ada di lingkungan sekitarnya. Informan mengaku adanya pengekangan dirinya oleh orangtua, diajarkannya harus bersikap baik dengan orang lain, kemudian ajaran agama, pemgetahuan dan etika juga diberikan dalam keluarga mereka. Seperti yang disampaikan oleh Richard Osborne \& Borin van loon (2005) bahwa kaum 
tradisionalis berpendapat bahwa disiplin itu penting bagi anak-anak. Yang lainnya menyatakan bahwa kasih sayang dan toleransi merupakan cara untuk menghasilkan diri-diri sosial yang baik....

Ajaran nilai dan norma telah diberikan kedua orangtua di lingkungan keluarga dan itu menjadi capaian ideal sebuah pendidikan ketika anak akan dapat mengikuti hal yang diajarkan sesuai keinginan dan harapan orangtua. Akan tetapi perintah dan pengekangan dengan batas-batasan yang diberikan dari orangtua secara berlebihan dan terlihat adanya komunikasi hanya satu arah saja maka berakibat kurang baik untuk anak-anak. Anak tidak mendapatkan kebebasan berpendapat ataupun bertindak sesuai dengan kemampuannya. Mereka lebih tergantung dengan orang tua sebagai orang yang dewasa. Sebagaimana yang disampaikan oleh Anthony Giddens (2003) bahwa anak dalam keluarga tradisional, baik dulu maupun sekarang, hanya perlu diawasi dan tidak didengarkan. Amat disayangkan bahwa banyak orangtua yang mungkin putus asa dengan sikap anak yang melawan mereka, ingin menegakkan aturan itu lagi.

Padahal telah kita ketahui bahwa seorang individu memiliki potensi yang berbeda satu sama lain sehingga individu merupakan hal yang unik. Anak sebagai individu seharusnya diberikan kesempatan untuk dapat mengeksplor segala kemampuannya dengan dibantu oleh orang tua sebagai seorang yang dewasa. Interaksi yang terjalin ada pada pilihan, secara intim (dekat) atau tidak. Kedekatan interaksi yang intensif terlihat adanya hubungan yang baik. Terciptanya hubungan yang baik adalah salah satunya dengan adanya komunikasi dua arah antara anak dan orangtua, hal tersebut seperti yang disampaikan oleh Anthony Giddens (2003) bahwa hubungan yang baik adalah hubungan yang setara, dimana setiap pihak mempunyai hak dan kewajiban yang sama...hubungan murni didasarkan sedemikan rupa pada komunikasi, sehingga memahami sudut pandang orang lain adalah sesuatu yang esensial. Perbincangan atau dialog, merupakan landasan yang membuat hubungan itu berjalan baik.

Pengasuhan yang diberikan orangtua berkontribusi dalam pembentukan karakter pribadi anak. Gaya pola pengasuhan setiap keluarga berbeda meskipun perempuan sexi dancer juga memiliki dan mengalami sepanjang usianya seperti layaknya orang lain. hal yang didapat di keluarga seperti diberikannya pengetahuan umum, nilai agama yang diyakini orangtua, bersikap baik pada orang lain, cuek dan ada yang tidak menekankan keagamaan dalam mendidik di keluarga. 
b. Pendidikan sekolah

Pendidikan di sekolah yang dialami informan sampai saat ini sedang mengenyam pendidikan formal di perguruan tinggi. Mereka mempunyai bakat yang apik sehingga tidak sulit bagi mereka untuk mempelajari tarian sexi yang sekarang ditekuni menjadi sebuah pekerjaan. Bahkan perguruan tinggi terkemuka yang ada di provinsi Yogyakarta sebagai tempat belajar secara akademis menjadi pilihan mereka. Informan mengakui untuk pendidikan formal mereka menargetkan harus selesai tingkat sarjananya. Disitulah juga mereka banyak belajar gerak tarian modern, terkadang untuk pertunjukan sexi dancer belajar dari managemen yang diikutinya atau merancang kreasi gerak tarian sendiri. Hal tersebut sudah biasa karena untuk informan yang belajar tari dibangku perkuliahan mereka memang dituntut bisa menciptakan gerakan tarian sendiri. Kreatifitas, fokus dan tekun dibutuhkan dalam mereka melakukan studi. Menurut James $\mathrm{M}$. Henslin (2007) bahwa masuk sekolah merupakan salah satu langkah signifikan dalam alih kesetiaan dan pembelajaran nilai baru. Cara baru untuk melihat dunia bahkan dapat menggantikan apa yang dipelajari anak di rumah... beranjak dari pendapat James M. Henslin tersebut bahwa ada nilai- nilai yang dipelajari baik itu nilai yang sudah menjadi kebiasaan ataupun nilai baru dalam dunia pendidikan formal sehingga terkadang sekolah menjadi rumah kedua untuk belajar semua kehidupan.

Sekolah sebagai tempat individu belajar hingga membentuk karakter diri pribadi menjadi sebuah harapan untuk lembaga mampu mendidik individu dengan hasil output yang maksimal, positif dan berguna dikehidupan masyarakat. Lembaga tersebut yang menjalankan fungsinya dengan baik menjadi tempat sosialisasi sekunder individu yang ideal serta sebagai tempat pelaksanaan pendidikan formal memberikan pengaruh yang signifikan. Semua hal yang berkaitan dengan pendidikan di sekolah berhubungan dengan peserta didik bahkan berkontribusi terhadap keberhasilan individu menjadi manusia seutuhnya dalam mencapai tujuan pendidikan sehingga akan mampu memberikan perubahan ke arah yang positif. Sebagaimana yang disampaikan dalam buku Nanang Martono (2014) bahwa pendidikan turut berperan serta dalam perubahan sosial di masyarakat. Menurut Foucault (1975), dengan pengetahuan yang dimilikinya, murid dapat ikut berperan melakukan perubahan sehingga ia tidak lagi menjadi objek yang hanya menerima pengetahuan ia akan berhubungan langsung dengan murid di sekolah. Ia juga 
mengawasi perkembangan prestasi

belajarnya.

c. Pendidikan masyarakat

$$
\text { Pembelajaran yang dialami }
$$
informan dari lingkungan yang lebih luas adalah dalam masyarakat. Mereka untuk terjun langsung ke dalam kegiatan masyarakat masih jarang mengingat statusnya adalah mahasiswa. Kegiatan selain di sekolah, mereka tetap mengikuti kegiatan-kegiatan layaknya mahasiswa lainnya seperti kegiatan bakti sosial, perkumpulan organisasi namun karena latar belakang menari mereka mengikuti perkumpulan menari bersama teman sebayanya. Klub tari yang diikuti dengan tujuan untuk meningkatkan kualitas diri dalam gerak tari karena selalu berlatih gerak dikelompok tersebut. Sejauh ini kegiatan yang diikuti informan masih bersifat positif dan tidak melanggar nilai norma masyarakat. Masyarakat yang memiliki nilai dan norma memberikan pembelajaran tersendiri untuk individu. Pembelajaran mereka sehingga akan berlaku sebagaimana harusnya di lingkungan masyarakat. seperti teori peran yaitu bahwa orang dalam hidup bermasyarakat senantiasa berusaha melakukan peran seperti dikehendaki oleh orang lain... identitas sesorang adalah dibentuk dalam rangka memberi respons dari perlakuan dan harapan orang lain (Sunyoto Usman, 2015).

Ketika peran yang dilakukan sebagai sexi dancer menjadi hal yang tidak sesuai menurut kelompok masyarakat tertentu maka keputusan untuk menyembunyikan identitas tersebut dilakukan oleh informan. Mereka berupaya agar tetap sesuai di masyarakat selayaknya nilai dan norma yang didapatkan meskipun harus memiliki dunia panggung yang disembunyikan untuk keluarga, teman secara luas ataupun masyarakat sekitarnya. Berbicara tarian sebenarrnya bukan hal yang dilarang namun jenis tarian ini yang lebih menitikberatkan pada gerakan sensual dan kostum minimalis yang dikenakan menjadikan tarian ini penuh warna pro dan kontra. Apalagi dengan penari adalah seorang wanita yang berada didepan penonton sebagian besar laki-laki, seringnya pertunjukan dilakukan di waktu malam hari.

Meskipun demikian, informan sebagai sexi dancer memiliki kehidupan pembelajaran yang ada di masyarakat. kegiatan yang diikuti mampu menunjukkan bahwa individu tidak bisa hidup sendiri dan membutuhkan bantuan orang lain juga tetap berinteraksi serta berbaur dengan masyarakat. Seperti yang diungkapkan oleh Gillin dan Gillin (1954) interaksi sosial merupakan hubungan-hubungan sosial 
yang dinamis yang menyangkut hubungan antara orang-orang-perorangan, antara kelompok-kelompok manusia, maupun antara orang perorangan dengan kelompok manusia. (Soerjono Soekanto, 2010). Ada kebiasaan dan aturan yang didapatkan dari masyarakat dan dipelajari oleh sexi dancer sebagai seorang individu dalam masa remaja akhir. Mereka tetap mendapatkan pengaruh dari interaksi sosial dan komunikasi yang terjadi di masyarakat meskipun dalam hal kegiatan kemasyarakatan belum totalitas mengikutinya.

\section{KESIMPULAN}

Berdasarkan hasil penelitian Fenomena Mahasiswa Perempuan Sebagai Sexi Dancer di Yogyakarta khususnya terkait dengan pendidikan mereka dapat disimpulkan bahwa gambaran dari 4 informan sebagai sexi dancer antara lain dalam hal pendidikan yang dialaminya yakni di keluarga bahwa adanya pengekangan dari orangtua, dipelajarinya nilai agama, pengetahuan umum dalam keluarga juga etika serta perbuatan baik dengan oranglain, untuk pendidikan sekolah saat ini mereka masih duduk dibangku perkuliahan dengan tujuan mendapatkan gelar sarjana, dan dalam masyarakat mereka belum terjun langsung namun mereka hanya mengikuti kegiatan yang ada di kampus dengan berorientasi berinteraksi dengan masyarakat sebagai contoh kegiatan KKN, bakti sosial, juri lomba dan sebagainya juga mereka mengikuti klub menari. Adanya temuan di lapangan bahwa untuk pekerjaan sebagai sexi dancer belum banyak orang yang mengetahui baik dari pihak keluarga maupun masyarakat, tetapi hanya beberapa teman mengetahui pekerjaan tersebut dilakukan selain berstatus sebagai mahasiswa. Mereka cenderung menutupinya dari keluarga.

\section{PERNYATAAN}

Ucapan terimakasih disampaikan kepada Fakultas Ilmu Sosial Universitas Negeri Yogyakarta sebagai lembaga sumber pendanaan penelitian kelompok Fakultas yang berjudul Fenomena Mahasiswa Perempuan Sebagai Sexi Dancer Di Kota Yogyakarta.

\section{DAFTAR PUSTAKA}

Agus, Salim. 2008. Pengantar Sosiologi Mikro. Yogyakarta : Pustaka Pelajar

Ellys Lestari Pambayun. 2010. Birahi Maya.Bandung : Nuansa.

Esti Ismawati. 2012. Ilmu Sosial Budaya Dasar. Yogyakarta : Ombak. 
Giddens, Anthony. 2003. Runaway World. Bagaimana Globalisasi Merombak Kehidupan Kita. Jakarta : PT. Gramedia Pustaka Utama.

Hamzah B. Uno. 2014. Teori Motivasi dan Pengukurannya Analisis di bidang pendidikan. Jakarta : Bumi Aksara.

James, M. Henslin. 2007. Sosiologi dengan Pendekatan Membumi. Jakarta : Erlangga.

Milles, B. Matthew \& Huberman, Michael, A. 1992. Analisis Data Kualitatif. Jakarta: UI Press.

Nanang Martono. 2014. Sosiologi Pendidikan Michel Foucault Pengetahuan, Kekuasaan, disiplin, Hukuman dan Seksualitas. Jakarta : PT Raja Grafindo Persada.

Panut Panuju \& Ida Umami. 2005. Psikologi Remaja. Yogyakarta : PT. Tiara Wacana Yogya.

Richard Osborne \& Borin van loon. 2005. Sosiologi. Batam : Scientific Press

Soerjono Soekanto. 2010. Sosiologi Suatu Pengantar. Jakarta : Raja Grafindo Persada.

Sunyoto Usman. 2015. Sosiologi Sejarah, Teori dan Metodologi. Yogyakarta: Pustaka Pelajar. 